\title{
A NEW FLIGHTLESS SPECIES OF THE GENUS TRICHIORHYSSEMUS CLOUËT, 1901, FROM MEXICO (COLEOPTERA APHODIIDAE: PSAMMODIINAE)
}

\author{
Riccardo PitTino \\ Via Zezon, 10 - 20124 Milano, ITALY. \\ riccardo.pittino@fastwebnet.it \\ RESUMEN
}

Se describe a Trichiorhyssemus hispidus sp.nov. del Estado de Veracruz, México, primera especie braquiptera conocida de este género. Se incluye también una clave para las especies de Trichiorhyssemus del hemisferio occidental.

Palabras clave: Scarabaeoidea, Aphodiidea, México, Trichiorhyssemus, especie nueva.

\begin{abstract}
The first known flightless species of Trichiorhyssemus Clouët, $1901-T$. hispidus sp. nov. - is hereby described and illustrated, from the State of Veracruz, Mexico. A key to Western Hemisphere species of the genus is also included.

Key words: Scarabaeoidea, Aphodiidea, Mexico, Trichiorhyssemus, new species.

\section{INTRODUCTION}

The study of unidentified Mexican Psammodiinae, submitted to me by my dear colleagues Enrique Montees de Oca and Marco Dellacasa, led me to discover a new species of Trichiorhyssemus Clouët, 1901, which is described and illustrated here. The allies of the new species are discussed, and a key to the Western Hemisphere species of the genus is given. The terminology used for anatomical parts of external morphology agrees with Pittino \& Mariani (1986).
\end{abstract}

\section{RESULTS}

Trichiorhyssemus hispidus sp. nov.

(Figs 1-3)

Type material. Holotype male. Mexico, Veracruz, Apazapan, $19^{\circ} 19^{\prime} 15^{\prime \prime} \mathrm{N} / 96^{\circ} 42^{\prime} 35^{\prime \prime} \mathrm{W}$, $280 \mathrm{~m}$, ground trap with cow dung bait on maize/pumpkin field ("milpa"), III.2000, E. 


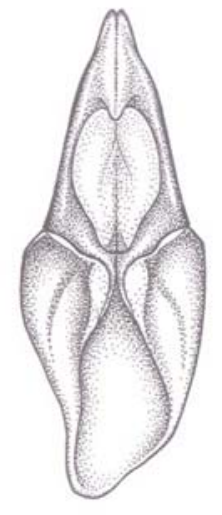

1

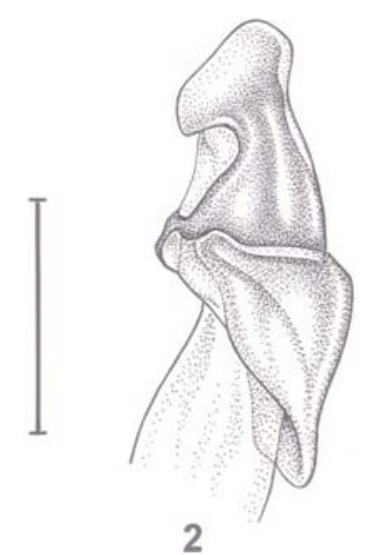

2

Figures 1-2

Trichiorhyssemus hispidus sp. nov., aedeagus, ventral (1) and lateral (2) views (paratype, Apazapan, Veracruz, Mexico). Scale bar: $0.2 \mathrm{~mm}$.

Montes de Oca \& Q. Santiago, deposited at the United States National Museum of Natural History (Smithsonian Institution), according to collectors'will. Paratypes: one male with the same data as the holotype in author's collection; another male: Mexico, Veracruz, Apazapan, $19^{\circ} 19^{\prime} 32^{\prime \prime} \mathrm{N} / 96^{\circ} 433^{\prime} 32$ ", $330 \mathrm{~m}$, ground trap with cow dung bait on pasture, I.2000 E. Montes de Oca \& Q. Santiago, kept in E. Montes de Oca's collection.

Diagnosis. Male (female unknown). Length 2.8 to $3.0 \mathrm{~mm}$, width 1.15 to $1.2 \mathrm{~mm}$. Body elongate-oval, widest at middle of elytra, moderately shiny, reddish to blackish brown, lighter near margins, darker on legs. Both dorsal and ventral sculptures originally almost entirely obscured by a thick layer of mud encrustation. All dorsal tubercles and elevations are markedly prominent. Pubescence is greyish yellow, dorsal setae clearly visible, forming distinct, erect, brush-like tufts on top of pronotal and elytral tubercles, ventral setae rather short, scale-like, almost recumbent. Dorsal habitus: Fig. 3.

Description. Head strongly convex; anterior clypeal margin weakly reflexed, angulate on either side near distinct median emargination; sides gently arcuate, barely notched near moderately produced, obtusely rounded, haired genae; tubercles rather coarse, uniform, prominent, evenly distributed; pair of occipital oblique ridges elevated, sharp, surrounded by close, small tubercles; eyes normally developed; marginal supraocular carina very distinct.

Pronotum strongly convex, nearly 1.25 times wider than long, widest at about middle, poorly attenuated anteriorly, visibly, though moderately, attenuated posteriorly; anterior angles rounded, distinctly produced, clearly declivous, coarsely tuberculate outwards, smooth inwards; sides widely arcuate, distinctly converging basally to obtuse, moderate posterior angles; base softly arched, sides and base finely margined, minutely crenate with fringe of evenly close, moderately long, flattened, obviously clavate setae; surface unevenly, closely, 


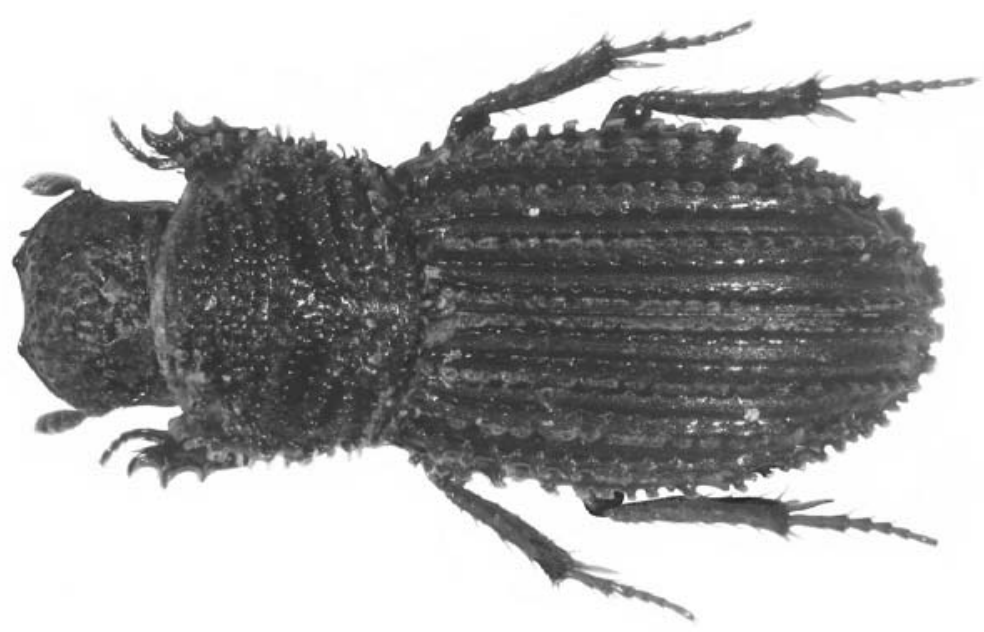

Figura 3

Trichiorhyssemus hispidus sp. nov., habitus, dorsal view (male paratype, length $2.9 \mathrm{~mm}$, Apazapan, Veracruz, Mexico).

coarsely tuberculate throughout; tubercles quite irregular in size and distribution, making sculpture hardly recognizable at first sight, but actually consisting of six transverse ridges, as many furrows, and single midline furrow interrupting last four ridges; all ridges formed of close, sharp, prominent, discrete tubercles with brush- like setose top; all furrows with clearly smaller, sparser, bare tubercles; first three ridges moderately elevated, clearly dilated medially, first two furrows very narrow, shallow, faintly indicated; 1st ridge well separated from $2^{\text {nd }} ; 2^{\text {nd }}$ almost entirely fused to $3^{\text {rd }} ; 3^{\text {rd }}$ ridge narrowly interrupted medially by anterior edge of midline furrow; $3^{\text {rd }}$ furrow very wide and deep, minutely shagreened, clearly granulate; last three ridges narrow, sharp, elevated, separated by fine, rather deep furrows; midline furrow sharply defined, deep, wide, stretched over basal two-fifths. Scutellum small, elongate, triangular, alutaceous, clearly depressed.

Elytra strongly convex, suboval, 1.45 to 1.48 times as long as wide, 2.08 to 2.1 times as long as pronotum; sides evenly arcuate, greatest width and height at about middle, base clearly bordered; humeral callus indistinct; humeral tooth very coarse, sharply pointed, obviously produced forwards; odd intervals, sutural one included, all composed of strongly elevated, sharp costae, top of costae with single row of subconical, prominent, sharply pointed, coarse tubercles, tubercles separated by about once their diameter, with brush-like, obviously setose top; even intervals almost flat, smooth, occasionally with single, scattered, minute, bare tubercles in apical half; striae deep, shiny, half as wide as even intervals, distinctly punctate; punctures separated by about twice their diameter, poorly crenating interstrial edges; all intervals reaching or almost reaching elytral apex except clearly shortened $8^{\text {th }}$ one; epipleural carina sharp, its top slightly wavy, weakly, sparsely tuberculate, with narrow tomentose rim. Metathoracic wings reduced to mere ribbons, lacking any venation. 
Mesocoxae widely spaced; mesosternum clearly impressed posteriorly on either side of mesosternal apophysis; apophysis triangular, moderately prominent, minutely scabrous, posteriorly slightly depressed, very wide, anteriorly strongly attenuated, extending into very narrow, sharp, elevated midline carina, almost reaching anterior mesosternal edge. Metasternum obviously shortened, anterior postcoxal transverse grooves indistinct with row of coarse punctures along mesocoxal posterior margin; posterior antecoxal grooves and metasternal triangles distinct; metasternal plate slightly depressed medially, midline furrow barely indicated; surface with rather coarse and close, irregular setose punctures throughout. Femora all straight, margined neither anteriorly, nor posteriorly; punctures setose, moderate, close on profemur, sparser on both other ones; profemur very plump, poorly attenuated apically, nearly 1.7 times longer than wide; mesofemur moderately plump, almost 2.4 times as long as wide; metafemur elongate, about three times as long as wide. Protibia clearly tridentate, apical spur robust, pointed, slightly bent down and outwards, about as long as first two tarsal joints combined; both meso- and metatibiae elongate, moderately dilated apically, visibly arcuate outwards, outer margin with single blunt denticle at about middle, lower apical edge with sparse unequal spines; metatibia very slender, about 4.7 times as long as wide; upper apical spur robust, slightly sinuous, apically pointed, clearly shorter than $1^{\text {st }}$ tarsal joint; metatarsus almost 9/10 as long as tibia, 1st joint elongate, scarcely dilated apically, about same length as next three ones combined. Claws corneous. Male genitalia (Figs. 1-2.): Parameres elongate, internal sac apically with dense spicules of the wall but no distinct sclerites.

Remarks. This is the first known flightless Trichiorhyssemus species in the world, thus readily recognized by characters related to microptery, like the indistinct humeral callus and the shortened metasternum. Three species of this genus were formerly quoted from the Western Hemisphere, namely T. riparius (Horn, 1871), T. cristatellus (Bates, 1887), and T. alternatus Hinton, 1938 (Gordon \& Cartwright 1980). They are all flightened, the complete wing development being indicated externally by the subparallel-sided elytra, distinct humeral calli and fully developed metasternum. The first two ones, of which only the latter occurs in Mexico, cannot be confounded with the new species, since they both bear all elytral intervals costate, at least in basal half. In contrast, T. alternatus, which is a Mexican species, actually presents alternate elytral intervals costate, but not as sharp and strongly elevated as in the new species, dorsal setae minute, nearly invisible, rather than coarse and apparent as in the new species, and all dorsal tubercles clearly smaller than in T. hispidus sp. nov. The four currently known Trichiorhyssemus species of the Western Hemisphere are recognized through the following key.

\section{Key to Western Hemisphere Trichiorhyssemus species}

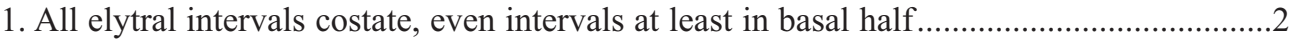

Odd elytral intervals costate, even intervals entirely flat.....

2. Pronotal ridges and furrows ill-defined, ridges subconfluent, furrows obsolete. Length: 2.7 to $3.1 \mathrm{~mm}$. Southwestern U.S.A................................T. riparius (Horn, 1871) Pronotal ridges and furrows sharply defined, ridges separate, furrows distinct. Length: 2.3 to $2.8 \mathrm{~mm}$. Mexico, Guatemala, El Salvador, Nicaragua. 
3. Flightened. Elytra elongate, subparallel-sided; humeri distinct; odd intervals clearly tectiform, rather high, with smooth continuous top. All dorsal tubercles moderate in size. Dorsal setae inconspicuous, dust- like. Length: 2.4 to $2.9 \mathrm{~mm}$. Mexico

T. alternatus Hinton, 1938

Flightless. Elytra short, suboval; humeri indistinct; odd intervals as very high costae, their top with row of coarse, prominent, pointed, separate tubercles. Dorsal setae coarse, apparent, forming distinct, brush-like tufts. Length: 2.8 to $3.0 \mathrm{~mm}$. Veracruz, Mexico T. hispidus sp. nov.

\section{ACKNOWLEDGMENTS}

I am indebted very much to my dear friends and colleagues: Enrique Montes de Oca (Veracruz), for allowing me to study valuable materials of Mexican Psammodiinae and keep one paratype of the new species for my collection; Marco Dellacasa (Pisa), for his kind good offices; Alberto Ballerio (Brescia), who took the photograph from dorsal view of the new species using the Auto-Montage system (Syncroscopy, Inc.); Miloslav Rakovič (Prague), for reviewing my the manuscript.

\section{LITERATURE CITED}

Gordon R.D. \& Cartwright O.-L. 1980. The Western Hemisphere Species of Rhyssemus and Trichiorhyssemus (Coleoptera: Scarabaeidae). Smiths. Contr. Zool., 317: 1-29.

Pittino R. \& Mariani G. 1986. A revision of the Old World species of the genus Diastictus Muls. and its allies (Platytomus Muls., Pleurophorus Muls., Afrodiastictus n.gen., Bordatius n.gen.) (Coleoptera, Aphodiidae, Psammodiini). G. it. Ent., 3: 1-165.

Recibido:1 de febrero de 2007

Aceptado: 4 de junio de 2007 